

\title{
Trend Analysis Variations and Relation Between Discharge and Rainfall: a Study on Kushiyara River
}

\author{
M. E. Uddin ${ }^{1}$, S. A. Akter ${ }^{1}$, M. J. Uddin ${ }^{2^{*}}$ and M. T. M. Diganta ${ }^{2}$ \\ ${ }^{1}$ Department of Geography and Environment, Shahjalal University of Science and \\ Technology, Sylhet \\ ${ }^{2}$ Department of Environmental Science and Resource Management, Mawlana Bhashani \\ Science and Technology University, Tangail \\ *Corresponding author: muhammadjasimuddin@yahoo.com
}

\begin{abstract}
Water resources and rivers play a very important role in economy and agriculture. But due to climate change and improper management, water resources are losing the natural discharge capacity from upper stream. This study was under taken to find out the trends and variability of rainfall and discharge at two stations of the Kushiyara River. Rainfall and discharge data Daily time series data of stream flow or discharge at Sheola (1976 to 2007) and Sherpur (1982 to 2007) and observed discharge data in certain interval from 2008 to 2016 have been analyzed in this study. For trend analysis, Mann-Kendall Test (MK) and Senôs Slope Estimator method were used as non-parametric test and relationship assessment was done by undertaking Pearsonôs Coefficient of Correlation. Annual discharge at Sheola and Sherpur station showed downward trend and maximum discharge was found downward trend at both stations. In Mannkendall test and Senôs Slope Estimator method showed downward trend in most cases. Climate change and improper land management may have influenced the present condition.
\end{abstract}

Key words: Annual and seasonal rainfall, Kushiyara river, Seasonal discharge, Trend analysis

\section{Introduction}

Water is an essential element for natural and artificial environment which is carried by rivers and provides the life generating-fuel to ecology (Islam and Sikder, 2016). If a country is considered as a human body then water is the blood of body and river is vein. The livelihood pattern of human being is largely depended on the river. Many historical ancient civilizations were developed on the bank of rivers (Spencer and Thomas, 1987). River serves the human race with different purposes. Many sectors of human society, including economy, culture, politics, transportation and agricultural characteristics have been influenced by river for thousands of years. River is a geographical feature. It rises generally from a mountain or lake. At first several very narrow streams of water join together and form one larger stream. This stream gradually widens in its course. On its way, it is joined by other smaller rivers. They are called its tributaries. At last the river falls into a sea, lake or another river. The mouth of the river becomes very wide A river generally receives its water by the melting of snow on mountains. Sometimes it is fed byrain. The origin of the water drains by the river is rainfall, river discharge and steam flow, melting of glaciers, base flow from groundwater, etc. (Raghunath, 2006). River discharge and rainfall are two the most important hydrological characteristics that govern the quantity of water in rivers (McMahon, 1982). River discharge is a powerful integrating tool and its monitoring can provide accurate and timely data to response of the land surface to atmospheric forces. It is also one of the accurately measured components of the hydrological cycle (Shiklomanov et al., 2006) and therefore can provide real-time estimation of water cycle trends and variability. Variability in rainfall characteristics (type, amount, frequency, intensity and duration) is among the important climate change impacts. Rainfall variability affects water resources sustainability which includes the availability, management, and utilization of water resources. This in turn may affect ecosystems, land productivity, agriculture, food security, water quantity and quality, and human health (EPA, 2014).

Due to climate change and human activities, many rivers are altering their discharges. Over the past decades, about $22 \%$ of the worldôs rivers showed statistically significant decrease in annual discharge (Walling and Fang, 2003) due to water consumption and diversion and reservoir construction, which is leading to great environmental problems (Wiegel, 1996; Trenhaile, 1997; Yang and Saito, 2003). Climate change has resulted in a decrease in discharge at Kushiyara River in Sylhet of Bangladesh (Nury et al., 2013).The dramatic decrease in discharge from the 
Yellow River (Huanghe) has led to great impacts on the economy of the delta and on the ecology of the adjacent sea (Tian, 1997; Ye, 1998; Cui, 2002). The decrease in water discharge has also reduced sediment supply and caused coastal erosion in many river systems (Jay and Simenstad, 1996; Wiegel, 1996; Yang et al., 1998; Yang and Saito, 2003). On the other hand, about $9 \%$ of the worldôs rivers showed statistically significant increasing trends in annual discharge (Walling and Fang, 2003). Increase in discharge usually occurs in high latitude rivers (Peterson et al., 2002; Manabeet al., 2004). For instance, the annual discharge of the Lena River in the Arctic increased by more than $10 \%$ from the 1940 s to the 1990s (Yang et al., 2002; Ye et al., 2003). In case of Rainfall, a significant increase has been found in the average annual rainfall of Bangladesh (Shahid, 2010) where decreased rainfall has been evidenced at Sylhet (Nury et al., 2013).

Bangladesh is an agricultural based country. All agricultural activities are largely depended onstream flow of river. Kushiyara River flows through Sylhet and Maulvibazar districts. So agricultural activities in adjacent area (Fenchugonj, Jokigonj, Bianibazar, Rajnagoretc) of Kushiyara River is depended on the discharge of Kushiyara River. Study of discharge trend o fKushiyara River shows the hydrologic condition of Kushiyara River. In a floodplain, land usepractices depend mainly on the depth of flooding due to population pressure, crop variety and intensity. Agricultural productivity, the choice of crops grown and the cropping pattern in the basin are also largely determined by hydrologic conditions (MPO, 1987). Though a lot of studies have been conducted on the trend of river discharge and variability rainfall all over the world but little attention has been paid to adjacent areas of Kushiyara River. For this reason objective of the study wasto assess the annual and seasonal discharge of Kushiyara River at Sheola station and
Sherpur station; to appraise the annual and seasonal rainfall of Kushiyara River at Sheola station; to analyze the trend of discharge of Kushiyara River at Sheola and Sherpur station; to find relation of discharge between Sheola and Sherpur station; to analyze the trends in Rainfall at Sheola Stationand to find relation between discharge at Sherpur station and rainfall at Sheola station.

\section{Materials and Methods}

This study area of this research was Kushiyara River within Sylhet and Maulvibazar district. Kushiyara River is a Trans-boundary Rivers of Bangladesh. Kushiyara River originates from the northern hills of Assam in India where it is known as Barak and then it flows further creating the border between Nagaland and Manipur states. The river enters Bangladesh along $24^{\circ} 53^{\prime}$ north latitudes and $92^{\circ} 32^{\prime}$ east longitudes after flowing westward from Milchar in Kachar district (India). Kushiyara River has a lengthof about $161 \mathrm{~km}$ with an average width of $250 \mathrm{~m}$ and in the monsoon season the mean depth of the Kushiyara reaches up to $10 \mathrm{~m}$.For the collection of hydrologic data, two gauging stations were selected which are known as Sheola and Sherpur. Sheola station locates in Sylhet district and Sherpur Station locates in Maulvibazar district. Selection of two gauging station was based some factors such as hydrologic conditions or characteristics are not same at all places of river course, upper stream and lower stream shows different characteristics of discharge, lower stream discharge always depends on upper stream discharge, rainfall station of Sheola which is located near the upper stream of river has contributed to lower stream discharge by runoff, base flow etc. Daily time series data of stream flow or discharge at Sheola (1976 to 2007) and Sher pur (1982 to 2007)and observed discharge data in certain interval from 2008 to 2016 have been analyzed in this study. Total period of discharge data is 42 years at Sheola station and 35 years at Sherpur station. 


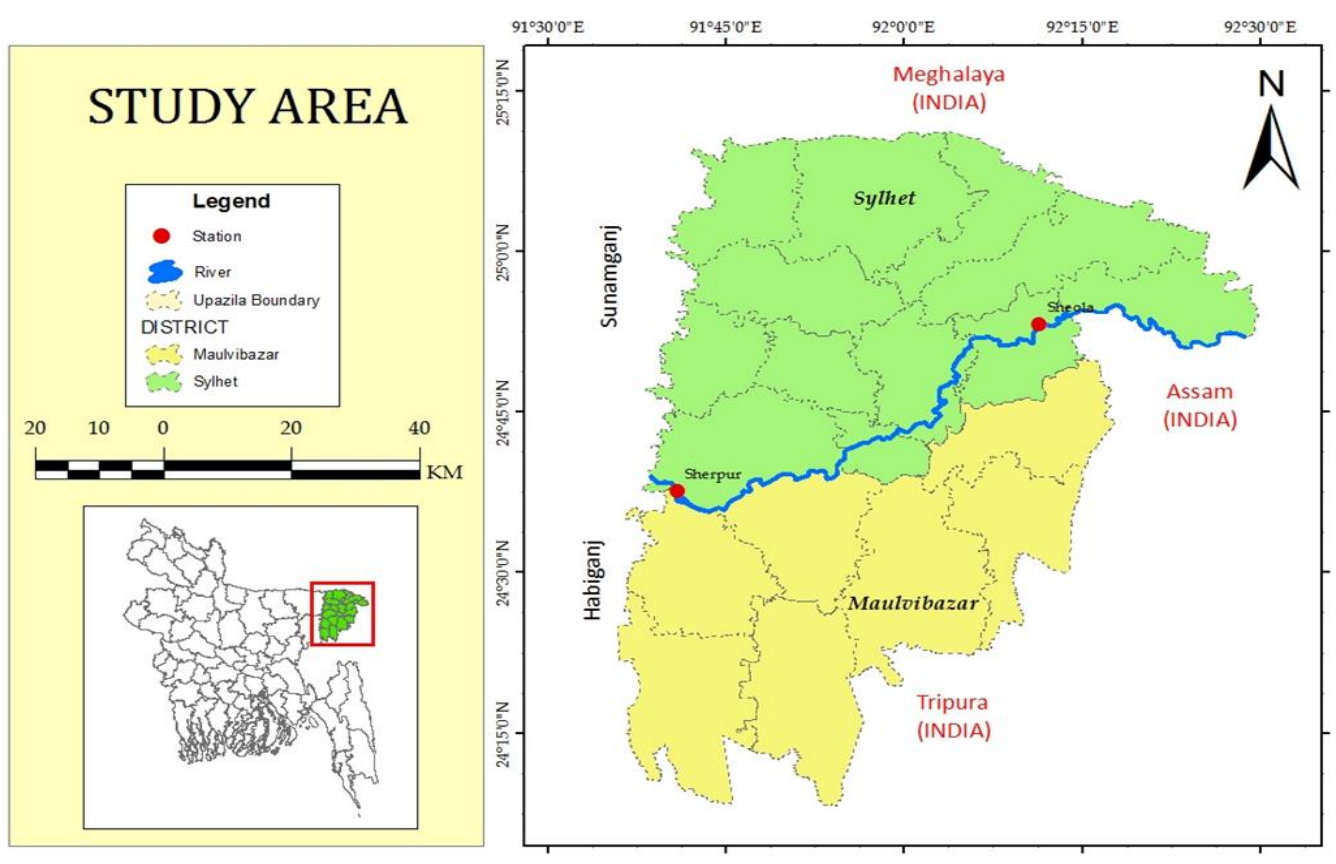

Map 01. Location of Sheola and Sherpur Station

In other hand, daily time series data of Rainfall at Sheola station have been analyzed. Time period of rainfall data is 40 years which is 1977 to 2016. All of time series data are secondary data which have been used in this study. These data are collected from government authorized organizations. Discharge (from 1976 to 2007) of Sheola station and discharge (from 1982 to 2007) of Sherpur station and rainfall (from 1977 to 2008) of Sheola station have been collected from National Water Resource Database (NWRD) founded and maintained by Water Resource Planning Organization (WARPO). Base map of Sylhet and Maulvibazar district are collected from website of Local Government Engineering Department (LGED).In trend analysis, there are two types of trend test which one is parametric test and another one is non-parametric test. Mann-Kendall Test (MK) and Senôs Slope Estimator method is used as nonparametric test. Non-parametric data is more reliable forhydrologic data. It was used to making decision on trend.

\section{Mann-Kendall's trend test}

The non-parametric Mann-Kendall test is commonly employed to detect monotonic trends in series of environmental data, climate data or hydrological data.The purpose of the Mann-Kendall (MK) test (Mann 1945; Kendall 1975; Gilbert 1987) is to statistically assess if there is a monotonic upward or downward trend of the variable of interest over time. Main benefit of this test is that the data need not conform to any particular distribution. No assumption of normality is required (Helsel and Hirsch, 1992). It is highly recommended for general use by World Meteorological Organization (Mitchell et al., 1966). The hypotheses of Mann and Kendallôs trend test is

$\mathrm{H} 0=$ Time series values are independent and identically distributed i.e. there is no trend.

$\mathrm{HA}=$ There is a monotonic (not necessarily linear) trend.

So, it is a teo-tailed test. The test statistic, S (score) is then computed as

$$
\mathrm{S}=\sum_{i=1}^{n-1} \sum_{j=i+1}^{n} \operatorname{sign}\left(y_{j}-y_{i}\right)
$$

Where, sign $\left(\mathrm{y}_{\mathrm{j}}-\mathrm{y}_{\mathrm{i}}\right)$ is equal to $+1,0$, or $-1, \mathrm{n}$ is the total number of observation. A positive value of $\mathrm{S}$ indicates an ápward trendôand a negative value of $\mathrm{S}$ indicates álownward trendô $\mathrm{It}$ has been documented that when $n>=8$, the statistic $S$ is approximately normally distributed with mean.

$\mathrm{E}(\mathrm{S})=0$

The variance statistic is given as

$$
\operatorname{Var}(\mathrm{s})=\frac{n(n-1)(2 n+5)}{18}
$$

Therefore, the test statistic $\mathrm{z}$ is calculated as

$$
\mathrm{Z}=\left\{\begin{array}{c}
\frac{(S-1)}{\sqrt{\operatorname{var}(S)}} \\
0, S=0 \\
\frac{(S+1)}{\sqrt{\operatorname{Var}(S)}, S<0}
\end{array}\right.
$$


$\mathrm{Z}$ follows standard normal distribution with mean zero and variance unity. A positive value of test statistic indicates a positive association means upward trend, a negative value of test statistic indicates a negative association means downward trend and test statistic $\mathrm{w}=$ equal zero means no association(no trend). The null hypothesis of no trend is rejected when $\mathrm{S}$ and $\mathrm{Z}$ are significantly different from zero.

\section{Sen's Slope estimator test}

This test computes both the slope (i.e. linear rate of change) and intercept according toSenôs method. First, a set of linear slopes is calculated as follows:

$$
\mathrm{T}_{\mathrm{i}}=\frac{x_{j}-x_{k}}{\mathrm{j}-\mathrm{k}} \quad \text { For } \mathrm{I}=1,2, \ldots \ldots . \mathrm{N}
$$

Where, $X_{j}$ and $X_{k}$ are considered as data value at time $j$ and $k(j>k)$ correspondingly. The median of these $\mathrm{N}$ values of $\mathrm{Ti}$ is represented as Senôs estimator of slope which is given as:

$$
\mathrm{Q}_{\mathrm{i}}=\left\{\begin{array}{cc}
\frac{T_{N+1}}{2} \quad N \text { is odd } \\
\frac{1}{2}\left(\frac{T_{N}}{2}+\frac{T_{N+1}}{2}\right) \quad N \text { is even }
\end{array}\right.
$$

Senôs estimator is computed as Qmed $=\mathrm{T}(\mathrm{N}+1) / 2$ if $\mathrm{N}$ appears odd, and it is considered as Qmed $=[\mathrm{TN} / 2+$ $\mathrm{T}(\mathrm{N}+2) / 2$ ] /2 if $\mathrm{N}$ appears even. At the end, Qmed is computed by a two sided test at $100(1-\breve{)}) \%$ confidence interval and then a true slope can be obtained by the non-parametric test. Positive value of $\mathrm{Q}_{\mathrm{i}}$ indicates upward or increasing trend and a negative value of $\mathrm{Q}_{\mathrm{i}}$ gives adownward or decreasing trend in the time series.

\section{Statistical Analysis}

Pearsonô coefficient of Correlation is used to show the relationship between variable. Discharge-discharge, discharge-rainfall relation is determined by correlation. Relation is spectacled by percentage. Probable error (PE) is calculated to examine the significance of correlation. Coefficient of correlation is calculated to determine the dependency rate of dependent variable on independent variable. All types of data were processed and analyzed by using Microsoft Office 2013, Minitab 18 and MAKESENS 10 . The Maps had been prepared by using Arc GIS 10.3 software. After data entry had been completed, simple one way tables and graphs had been prepared for the analysis to make the report more understandable.

\section{Results and Discussion}

Assessmentof annual and seasonal discharge of Kushiyara river at Sheola station and Sherpur station Annual mean, maximum and minimum discharge at Sherpur station is higher than Sheola station (Table 1). Mean discharge at Sheola is varied from 1010.345 to $463.68 \mathrm{~m}^{3} / \mathrm{s}$ and mean discharge at Sherpur station was lied between $1434.039 \mathrm{~m}^{3} / \mathrm{s}$ (1986) and $783.67 \mathrm{~m}^{3} / \mathrm{s}$ (2003). Maximum discharge at Sheola varied from 2960 to $1413.14 \mathrm{~m}^{3} / \mathrm{s}$ while Sherpur varied from 3950 to $1727.34 \mathrm{~m}^{3} / \mathrm{s}$. Minimum discharge at Sheola varied from 122 to 25.02 while Sherpur varied from 176.86 to 16.36 . From the above findings, it could be said that water discharge at downstream (Sherpur) is higher than upstream (Sheola).

Table 1. Annual discharge scenario at Sheola and Sherpur Staion.

\begin{tabular}{lrr}
\hline Indicators $\left(\mathrm{m}^{3} / \mathrm{s}\right)$ & Sheola Station & Sherpur Station \\
\hline Mean Discharge & 738.9 & 970.17 \\
Highest Mean Discharge & $1010.345(1990)$ & $1434.039(1986)$ \\
Lowest Mean Discharge & $463.68(1979)$ & $783.67(2003)$ \\
Annual Mean Maximum Discharge & 2138.92 & 2251.7 \\
Annual Mean Minimum Discharge & 64.9 & 92.55 \\
Highest Annual Maximum Discharge & $2960(1983)$ & $3950(1991)$ \\
Lowest Annual Maximum Discharge & $1413.14(2014)$ & $1727.34(2009)$ \\
Highest Annual Minimum Discharge & $122(1992)$ & $176.86(2000)$ \\
Lowest Annual Minimum Discharge & $25.02(1999)$ & $16.36(2016)$ \\
\hline
\end{tabular}

There was also noticeable difference of discharge at Sheola and Sherpur station. Rainfall, runoff and tributaries contribute to being high discharge at Sherpur than Sheola (Fig 1, Fig 2). Seasonal discharge of both Sheola and Sherpur station has been visualized in Fig. 3 and found that there was significant difference between Sheola and Sherpur discharge in summer and winter season. Monsoon discharge at Sheola and Sherpur station is nearly same. Summer and winter discharge at downstream than station is higher upstream station. Monsoon discharge at downstream is lower than upstream station. Climate change could be the possible reason for such findings. 


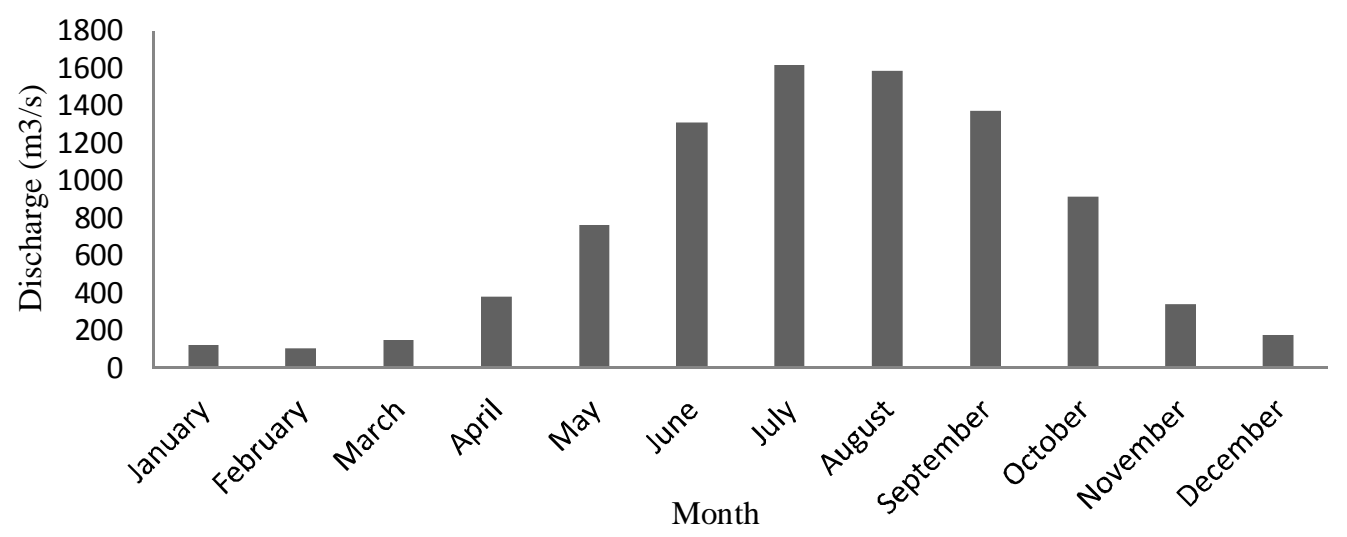

Fig. 1. Mean monthly discharge at Sheola station.

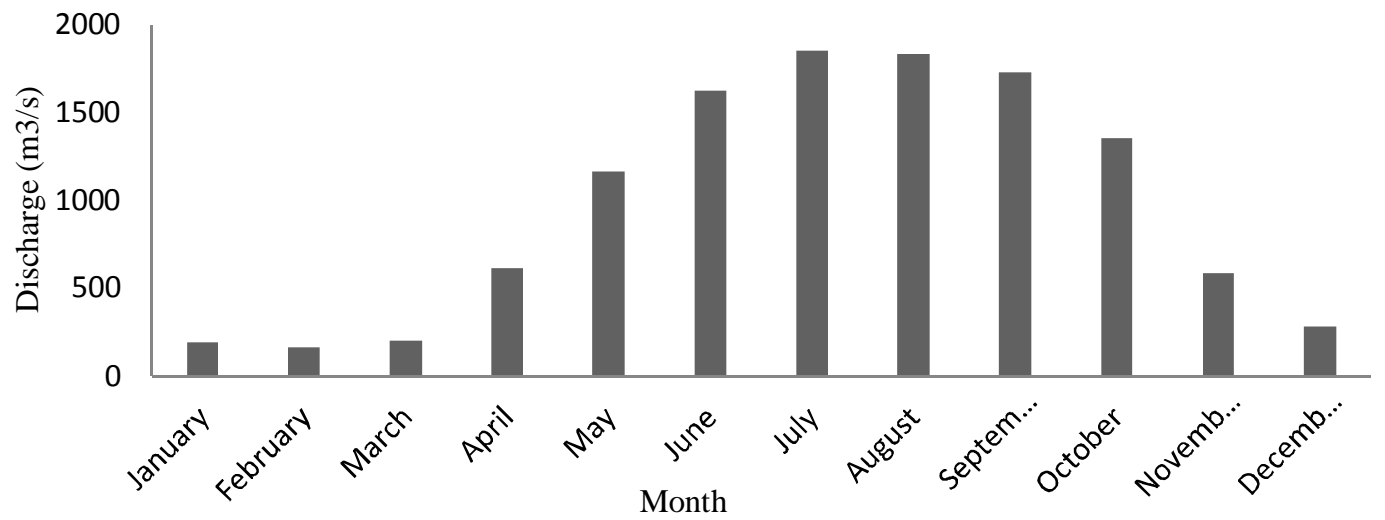

Fig. 2. Mean monthly discharge at Sherpur station.

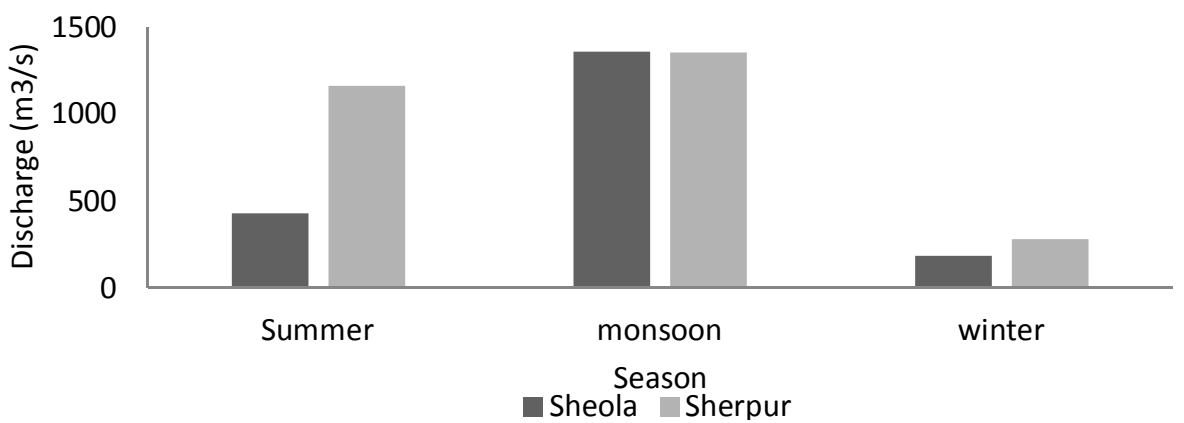

Fig. 3. Seasonal mean discharge at Sheola and Sherpur Station

Appraisal of the annual and seasonal rainfall of Kushiyara River at Sheola station
Annual mean rainfall at Sheola was $4016.62 \mathrm{~mm}$ (Table 2). The highest rainfall (5516 mm) was occurred in 1991 and lowest in 2006. 
Table 2. Seasonal mean discharge at Sheola and Sherpur station

\begin{tabular}{ccc}
\hline Season & \multicolumn{2}{c}{ Seaasonal Mean Discharge $\left(\mathrm{m}^{3} / \mathrm{s}\right)$} \\
\hline & Sheola & Sherpur \\
\cline { 2 - 3 } Summer & 429.6878 & 1163.482 \\
Monsoon & 1358.402 & 1352.564 \\
Winter & 186.665 & 281.8263 \\
\hline
\end{tabular}

Analysis of mean monthly rainfall at Sheola station revealed that highest rainfall occurred in June and lowest in January (Fig. 4). Seasonal mean of rainfall data showed that highest rainfall occurred in Monsoon season and lowest in winter season (Fig. 5). This revealed that from March to May, Kushiyara River receives maximum rainfall in a year and from November to February, it receives minimum rainfall in a year.

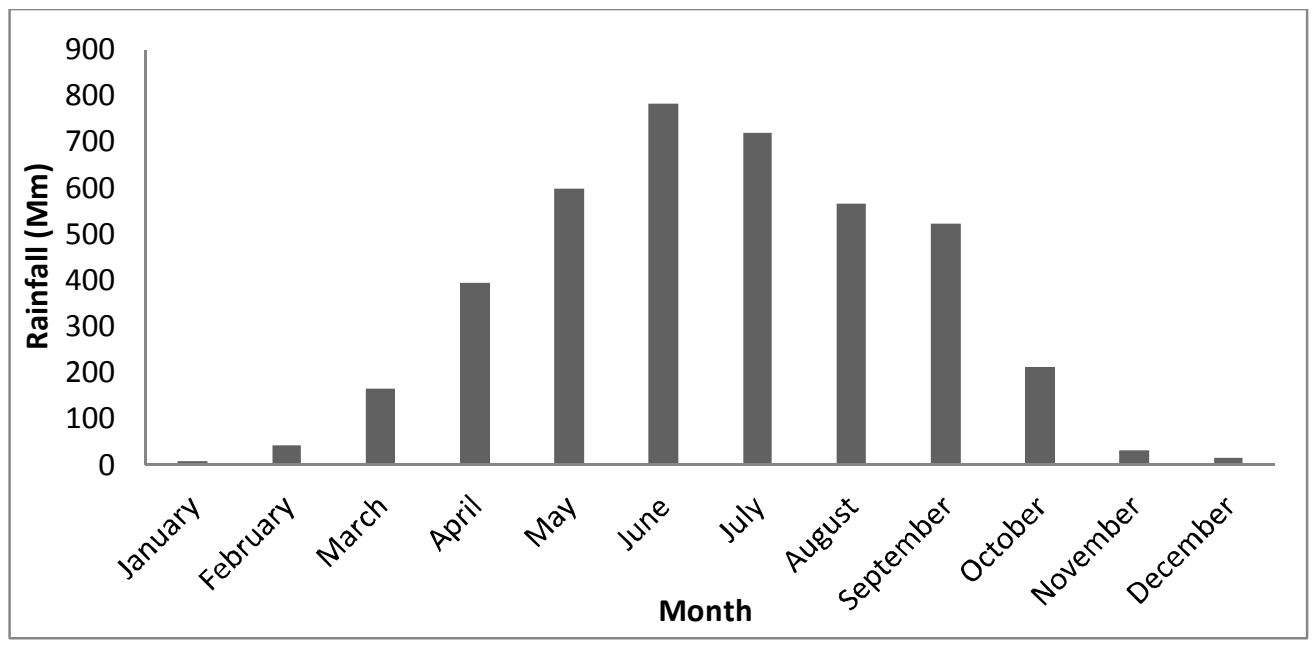

Fig. 4. Mean monthly rainfall at Sheola station

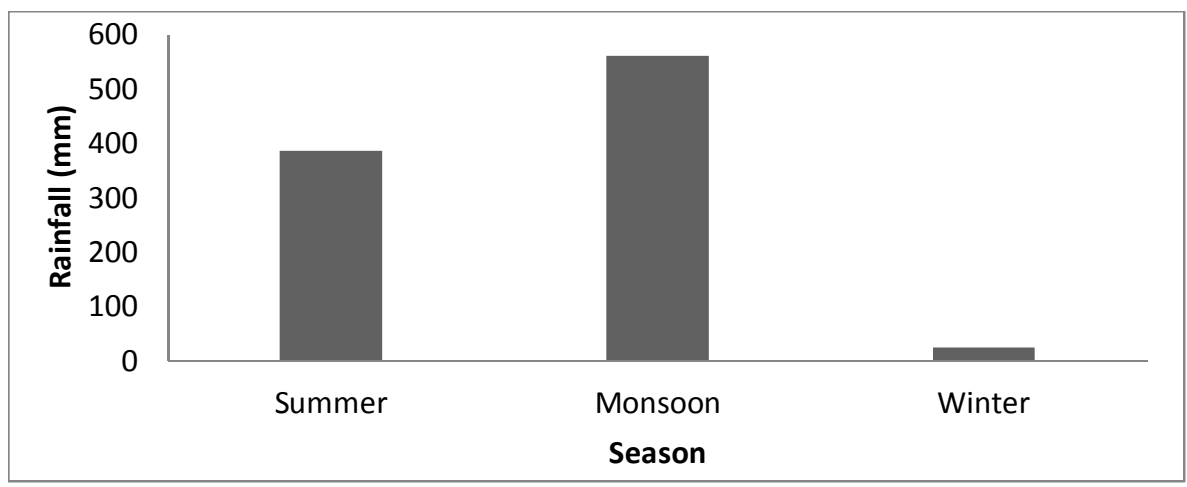

Fig. 5. Seasonal mean rainfall at Sheola station.

\section{Trends in discharge at Sheola and Sherpur station}

Non-parametric tests such as Mann-Kendall test and Senôs slope estimation have been conducted to find out the trend in annual mean discharge at Sheola and Sherpur station. A total 35 yearôs (1982 to 2016) data has been used for trend analysis. Values of MannKendall Test and Senô Slope have been presented in
Table 3. Negative value of $\mathrm{Z}$ indicates the downward trend at Sheola and Sherpur station but not significant at $95 \%$ significance level. Significance or insignificance is determined by $\mathrm{P}$-value. P-value of Sheola and Sherpur station are 0.174304 and 0.1817 both respectively. P-value of both stations are higher than $\breve{U}(=0.05)$. Significance of trend be evident when 
P-value is lower than $\breve{U}(=0.05)$ and insignificance of trend be evident when $\mathrm{P}$-value is higher than $\breve{U}(=0.05)$. Senô Slope Estimator has been used to calculate the slope of discharge change. Value of Senôs Slope gives the change per unit time period (in per year). Positive value of Senôs Slope indicates upward trend and negative value of Senôs Slope indicates downward trend. Value of Senôs Slope at Sheola and Sherpur station is -2.186 and -1.806 respectively. So these values acquaint that discharge at Sheola station and Sherpur station is downward. Both MK Test and Senôs Slope shows the decreasing trend at Sheola station and Sherpur station. So finally it concluded that decreasing trend at Sheola station is high rate than the decreasing trend at Sherpur station. Trends of both stations are insignificant trend.

Table 3. Mann-Kendall test and Senôs Slope value of annual mean discharge

\begin{tabular}{|cccc|}
\hline \multicolumn{3}{c|}{ Mann-Kendall Test } \\
\hline Station & Pent Statistic Z & P-value & Senope \\
& Testop & -2.186 \\
Sheola & -0.937295 & 0.174304 & -1.806 \\
Sherpur & -0.9088 & 0.1817 & \\
\hline
\end{tabular}

In the trend analysis of seasonal mean, estimated values of Mann-Kendall test and Senô Slope has been presented in Table 4. In Sheola station, it appears that trends of mean seasonal discharge in winter showed upward trend. Winter mean discharge trend is statistically significant due to p-value $(0.0218935)$ is lower than $\breve{U}(=0.05)$. Monsoon and summer discharge trends showed downward trends and trends are statistically insignificant. Here P-value is higher than U value. On the other hand, Sherpur station showed that trends of summer and monsoon indicates downward trend and trends is statistically insignificant. P-value of summer and monsoon is 0.0777830 and 0.432341 respectively. These p-values are higher than Ŭ value. Winter seasonal mean discharge at Sherpur station shows upward trend and it also statistically insignificant due to P-value $(0.247643)>\breve{U}$ value. So from this test, it showed similar results like upstream station (Sheola) has been showed downward or decreasing trend and downstream station (Sherpur) has been showed downward or decreasing trend in summer monsoon. In winter, though both stations indicated upward trend but downstream trend was lower than upstream trend.Here only in winter both Sheola and Sherpur Station showed increasing trend. Senôs Slope value gave a hint of the change of time series data variables. SenôSlope value of summer, monsoon and winter of Sheola station are $-2.323,-6.141$ and 2.163 respectively and value of summer, monsoon and winter of Sherpur station are $-6.838,-0.216$ and 1.114 respectively.

Table 4. Mann-Kendall and Senôs slope value of seasonal mean discharge

\begin{tabular}{|c|c|c|c|c|c|c|}
\hline \multirow[t]{3}{*}{ Station } & \multicolumn{3}{|c|}{ Sheola } & \multicolumn{3}{|c|}{ Sherpur } \\
\hline & \multicolumn{2}{|c|}{ Mann-Kendall Test } & \multirow[b]{2}{*}{ Senô Slope } & \multicolumn{2}{|c|}{ Mann-Kendall Test } & \multirow[b]{2}{*}{ Senôs Slope } \\
\hline & Z-value & P-value & & Z-value & P- Value & \\
\hline Summer & -0.511252 & 0.304587 & -2.323 & -1.42014 & 0.0777830 & -6.838 \\
\hline Monsoon & -1.36334 & 0.0863881 & -6.141 & -0.170417 & 0.432341 & -0.215 \\
\hline Winter & 2.01612 & 0.0218935 & 2.163 & 0.681924 & 0.247643 & 1.114 \\
\hline
\end{tabular}

Value of Mann-Kendall Test and Senôs Slope estimation for maximum and minimum discharge has been exhibited to Table 5. In Mann-Kendall Test maximum discharge at Sheola and Sherpur station was downward and statistically significant. P-value of those stations are lower than $\breve{U}(=0.01)$ value which is significant at $99 \%$ significance level. For minimum discharge, Sheola and Sherpur station showed upward 
trend and these trends are statistically insignificant. Because P-value of both station is higher than $\breve{U}$ $(=0.05)$ value. Senô Slope value shows the magnitude of change of trends. Positive value of Senôs Slope indicates upward or increasing trend. Negative value of
Senô Slope indicates downward or decreasing trend. Senôs Slope value of maximum and minimum at Sheola station is -30 and 0.003 . On the other hand maximum and minimum at Sherpur station is -20.438 and 0.397 .

Table 5. MK Test, Senôs Slope statistics of annual maximum and minimum discharge

\begin{tabular}{|c|c|c|c|c|c|c|}
\hline Station & \multicolumn{3}{|c|}{ Sheola } & \multicolumn{2}{c|}{ Sherpur } \\
\hline Parameter & \multicolumn{2}{|c|}{ Mann-Kendall Test } & \multirow{2}{*}{ Senôs Slope } & \multicolumn{2}{c|}{ Mann-Kendall Test } & Senôs Slope \\
& Z-value & P-value & & Z-value & P-value & \\
\cline { 2 - 6 } & & & & -3.82057 & 0.0000666 & -20.438 \\
Maximum & -5.42495 & 0.000 & -30 & 0.866608 & 0.193078 & 0.397 \\
\hline
\end{tabular}

\section{Relationship of discharge between Sheola and Sherpur station}

Pearsonô coefficient of correlation was conducted to measure relation between both stations. Discharge of Sheola station was considered as independent variables and discharge of Shepur station as dependent variable. Reason behind this consideration is Sheola station locates in upstream river and Shepur station locates in downstream river. So discharge of downstream is always depended on upstream discharge. The findings have been presented in Table 6, Table 7 and Table 8 . Table 6 shows the result of correlation of annual mean discharge at both stations. In this table, it seems that value of $r$ is 0.762648 which is closer to +1 .

Table 6. Correlation of annual mean discharge at Sheola and Sherpur station

\begin{tabular}{|cccccc|}
\hline Independent Variable & Dependent Variable & $\mathrm{r}$ & P.E. & $\mathrm{r}^{2}$ & $\mathrm{r}^{2}$ in $\%$ \\
\hline $\begin{array}{c}\text { Annual Mean Discharge at } \\
\text { Sheola Station }\end{array}$ & $\begin{array}{c}\text { Annual Mean Discharge at } \\
\text { SherpurSation }\end{array}$ & 0.762648 & 0.048 & 0.5816 & 58.16 \\
\hline
\end{tabular}

That means there has strong positive relation between both stations. Value of óôis significant because óôis six times greater than P.E. (0.048). $\mathrm{r}^{2}$ (0.5816) determine the proportion that means $58.16 \%$ discharge of Sheola station depends on the the discharge of Sherpur station. Statistically it calculated that a medium portion of discharge of Sherpur station is depends on the discharge of Sheola station. $41.84 \%$ discharge of other water sources rather than discharge of Sheola. The other water source may be some local water source like rainfall, run-off from land fall into river and juri river loctates after Sheola station. Manu River contributes the discharge of water which came from the station of Sheola. These sources could have sound effect on the discharge of Sherpur station. Minor change of discharge at Sherpur station is occurred by local source and major change occurred by the discharge of Sheola station. From Table 7, it can be observed that the value of óô of all three seasons is positive and nearly close to +1 . As a result, it can be said that discharge of Sherpur station is strongly depends on the discharge of Sheola station. Rate of dependency of seasonal mean discharge are summer $(89.21 \%)$, monsoon $(38.72 \%)$ and winter $(62.96 \%)$. In this percentage, it could be said that there are strong relation of summer mean discharge between both stations. But surprisingly, there is nearly moderate relation of discharge between both stations in monsoon. Discharge of water which maybe came from the Sheola station could be retreated by other ways like irrigation, channels and other activities is likely to be the reason of moderate relationship. In winter, there was moderate relation between both stations.

Correlation from Table 8 exhibited that the value of óô is positive that means there has positive relation. óô 
value of maximum discharge is less nearly to +1 and óôvalue of minimum discharge is far from +1 , nearly to 0.5. P.E. value determines the significance of correlation. For maximum discharge, órô value is six times higher than P.E. of maximum. So this correlation of maximum discharge is significant. On the other hand, óôvalue of minimum discharge is not six times higher than P.E. of minimum. As a result, this correlation of minimum discharge is insignificant. $45.46 \%$ of maximum discharge of Sherpur station is depends on the maximum discharge of Sherpur station. $13.3 \%$ of minimum discharge of Sherpur station is depends on the minimum discharge of Sheola station.

Table 7. Correlation of seasonal mean discharge at Sheola and Sherpur station

\begin{tabular}{|cccccc|}
\hline Independent Variables & Dependent Variables & $\mathrm{r}$ & P.E. & $\mathrm{r}^{2}$ & $\mathrm{r}^{2}$ in $\%$ \\
\hline (Sheola Station) & (Sherpur Station) & & & & \\
Mean Discharge in Summer & Mean Discharge in Summer & 0.99453 & 0.012 & 0.8921 & 89.21 \\
Mean Discharge in Monsoon & Mean Discharge in Monsoon & 0.622301 & 0.071 & 0.3872 & 38.72 \\
Mean Discharge in Winter & Mean Discharge in Winter & 0.793479 & 0.042 & 0.6296 & 62.96 \\
\hline
\end{tabular}

Table 8. Correlation of maximum and minimum flow at Sheola and Sherpur station

\begin{tabular}{|cccccc|}
\hline Independent variables & Dependent variables & $\mathrm{r}$ & P.E. & $\mathrm{r}^{2}$ & $\mathrm{r}^{2}$ in $\%$ \\
\hline Maximum Flow at Sheola & Maximum Flow at Sherpur & 0.674292 & 0.063 & 0.4546 & 45.46 \\
Minimum Flow at Sheola & Minimum Flow at Sherpur & 0.364703 & 0.1 & 0.133 & 13.3 \\
& & & & & \\
\hline
\end{tabular}

\section{Trends in rainfall at Sheola station}

Table 9 shows the seasonal rainfall trend at Sheola station. It is spectacled that summer and monsoon rainfall indicates downward trend and winter rainfall notifies upward trend. Mann-Kendall Test of all seasonal rainfall is statistically insignificant. Statistically significance or insignificance is depended on P-value. If P-value is higher than $\breve{U}(=0.05)$ value then it is insignificant trend. When P-value is lower than $\breve{U}(=0.05)$ value then it is significant trend. Negative value of Senô Slope indicates the downward and positive value of Senôs Slope indicates upward trend. Senô Slope values of all seasonal rainfall are negative which means there has downward trend. Senô Slope values of summer, monsoon and winter are $-6.615,-3.724$ and 0.433 respectively.

Table 9. Mann-Kendall and Senôs slope test trend of seasonal rainfall at Sheola station

\begin{tabular}{|c|c|c|c|}
\hline \multirow{2}{*}{ Season } & \multicolumn{2}{|c|}{ Sheola Station } \\
\cline { 2 - 3 } & Z-value & Senôs Slope \\
\cline { 2 - 4 } & -1.16518 & 0.121973 & -6.615 \\
Summer & -0.466073 & 0.320582 & -3.724 \\
Monsoon & 0.662502 & 0.742961 & 0.433 \\
Winter & & \\
\hline
\end{tabular}

Insignificant trend means there has no enough evidence to detect trend. Seasonal rainfall is delineated in Fig. 6. Decreasing trend of summer and monsoon rainfall will hamper on the flow of Kushiyara River and agricultural activities (irrigation) in Sheola region. In winter, excessive rainfall can impede on agricultural activities in winter. 


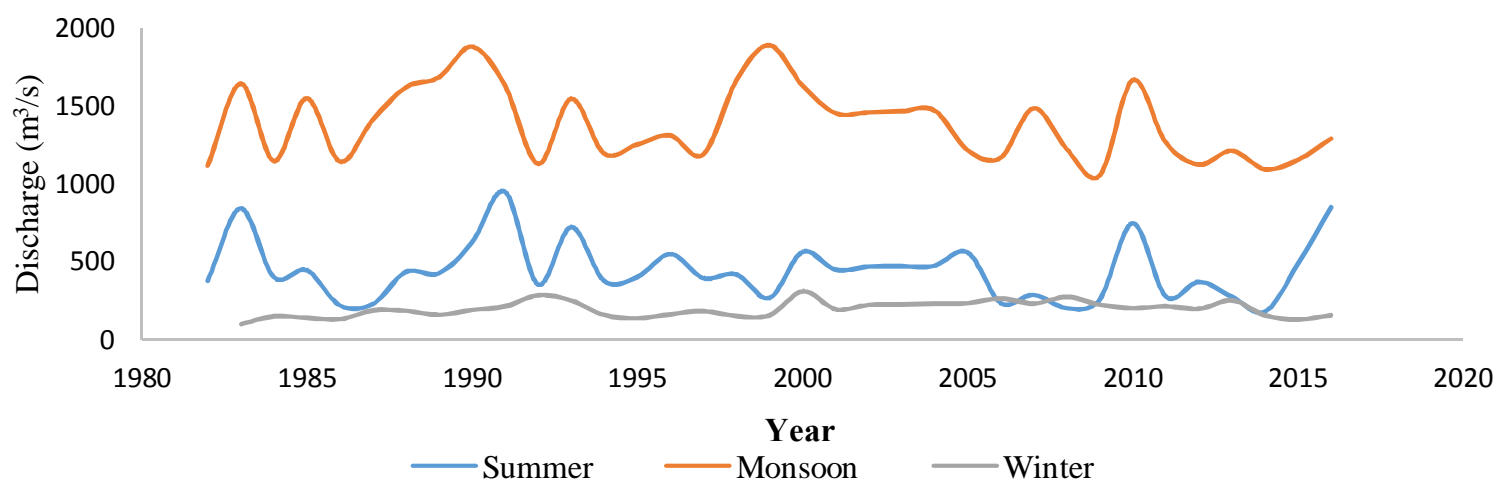

Fig. 6. Seasonal mean discharge at Sheola station

\section{Relationship between discharge at Sherpur station} and rainfall at Sheola station

The main hydro-meteorological quantities (rainfall and river discharge) has beencorrelated and presented in Table 10 and Table 11. 35 years (From 1982 to 2016) time periods of rainfall data at Sheola station and discharge of Kushiyaraô River at Sherpur station has been analyzed. Here rainfall considered as an independent variable and discharge considered as dependent variable. In Table 10, the correlation between annual rainfall at Sheola station and discharge at Sherpur station have been presented. The correlation table shows the correlation and dependency rate between discharge at Sherpur station and rainfall at Sheola station. In this table, it appears that ñò is positive. There has a positive correlation between discharge and rainfall. Value of ñò is 0.605353 which is nearly close to +1 . That means there has strong relationship. Correlation is significant because ñò is six times higher than probable error (P.E.). ñ ${ }^{2}$ ò determine the percentage of dependency. From table $7.1,36.64 \%$ of discharge at Sherpur station is fed by rainfall of Sheola station.

Table 10. Correlation between rainfall at Sheola station and discharge at Sherpur station

\begin{tabular}{|cccccc|}
\hline Independent Variable & Dependent Variable & r & P.E. & $\mathrm{r}^{2}$ & $\mathrm{r}^{2}$ in $\%$ \\
\hline Rainfall at Sheola Station & Discharge at Sherpur Station & 0.605353 & 0.0722 & 0.3664 & 36.64 \\
\hline
\end{tabular}

Rest of $63.36 \%$ of discharge at Sherpur station is contributed by other source like tributaries (Juri River, Manu River etc), stream flow from upper course, rainfall at Barak River basin etc.

In Table 11 the calculated data of correlation between seasonal rainfall at Sheola station and discharge at Sherpur station has been presented. From Table 10, it seems that ñò value of correlation of summer, monsoon and winter are 0.497274, 0.490676 and 0.33923 respectively. Value of r̃ò is positive. So there has positive relationship between rainfall at Sheola station and discharge at Sherpur station. But relations between variables are insignificant. Reason behind this insignificancy is values of ñò are not six times higher than probable errors (P.E.) values. $\tilde{n}^{2}$ ò determine the percentage of correlation.From percentage value, it indicates that correlation between rainfall and discharge of summer and rainfall and discharge of monsoon is nearly same. Relation percentages are $24.72 \%$ and $24.07 \%$ respectively. So it can be explained as there is closer rainfall variability in summer and monsoon season. In winter, correlation between rainfall and discharge is $11.5 \%$. Correlation in winter is lower than summer and monsoon season. 
Table 11. Seasonal correlation between rainfall at Sheola station and discharge at Sherpur station

\begin{tabular}{|c|c|c|c|c|c|}
\hline Independent Variables & Dependent Variables & \multirow[t]{2}{*}{$\mathrm{r}$} & \multirow[t]{2}{*}{ P.E. } & \multirow[t]{2}{*}{$\mathrm{r}^{2}$} & \multirow[t]{2}{*}{$\mathrm{r}^{2}$ in $\%$} \\
\hline (Rainfall at Sheola Station) & (Discharge at Sherpur Station) & & & & \\
\hline Summer Rainfall & Summer Discharge & 0.497274 & 0.085 & 0.2472 & $24.72 \%$ \\
\hline Monsoon Rainfall & Monsoon Discharge & 0.490676 & 0.086 & 0.2407 & $24.07 \%$ \\
\hline Winter Rainfall & Winter Discharge & 0.33923 & 0.1 & 0.115 & $11.5 \%$ \\
\hline
\end{tabular}

\section{Conclusions}

Main targets of study are trend analysis, relation of discharge and rainfall. Mann-kendall test, Senôs slope and correlation have been conducted to achieve these targets. Besides these, monthly variation of rainfall and discharge have been analyzed in this study. Coefficient of variation hasbeen used to find monthly variation. Statistical methods have been conducted to this study. Fromthis research, it has been appeared that annual discharge of Kushiyara River is decreasing and rainfall at Sheola station is also decreasing. Sedimentation, transportation, irrigation and fishing are strongly links to river. Decreasing trend of yearly discharge at Kushiyara River might affect the water demand to meet the needs of growing communities, farmers, energy producers and manufacturers. Irrigation and navigation would be affected severely. Rainfall is decreasing year to year. Irrigational and sedimentation activities will be hampered due to scarcity of rainfall. In winter season, monthly variation of rainfall is maximum than other seasons. So it needs to take proper plans for replenish the surface water management otherwise surface water condition would be worse. Based on this study following recommendations were made:

- Annual mean discharge is decreasing. Proper plan of surface water consumption for irrigation is necessary to be prepared. Implementation of plan is needed to be monitored.

- Changing of Kushiyara river discharge and rainfall is not isolated phenomena. It links to climate change. So it needs to take policy to face climate change and adapt climate change.

- Decreasing rainfall has huge impacts on agricultures or other activities. Suitable surface water management should be taken to replenish these activities.

- Discharge and rainfall trends showed statistically not significant. This happen due to small sample size. To avoid this, it must to take large sample size for future studies.
- Fluctuation of rainfall is high in winter. That may causes for many environmental and agricultural damages. It should be taken proper policy to reduce these impacts.

\section{References}

Cui, S. Q. 2002. Influence of water discharge cut-off of Huanghe on environment of its Delta. Marine Sci., 26(7), $42 \ddot{i} 46$.

Gilbert, R.O. 1987. Statistical Methods for Environment Pollution Monitoring. New York: Wiley.

Helsel, D. R. and Hirsch, R.M. 1992. Statistical Methods in Water Resources. Amsterdam: Elsevier Science Publications.

Islam, M. S. and Sikder, M. B. 2016. Hydrological characteristics analysis of Surma River in northeastern bangladesh: a quantitative approach. DIU Journal of Science and Technology, 11(2): 39-47.

Jay, D. A. and Simenstad, C. A. 1996. Downstream effects of water withdrawal in a small, highgradient basin: erosion and deposition on the Skokmish River delta. Estuaries, 19(3): $501 і$ 516.

Kendall, M.G. 1975. Rank Correlation Methods, 4th edition, London: Charles Griffin.

Manabe, S.; Milly, P. C. D. and Wetherald, R. 2004. Simulated long-term changes in river discharge and soil moisture due to global warming. Hydrol. Sci. J., 49(4): 625 ï 642.

Mann, H. B. 1945. Non-parametric tests against trend. Econometrica 13: 163-171.

McMahon, T.A. 1982. Hydrological characteristics of selected rivers of the world. Technical document in hydrology, Paris: UNESCO.

MPO, 1987. National Water Management Plan: Phase II, Final Report, Master Planning Organization. 
Mitchell, J.M.; Dzerdzeevskii, B.; Flohn, H.; Hofmeyr, W.L.; Lamb, H.H.; Rao, K.N. and Walleô, C.C. 1966. Climate change. WMO Technical Note No. 79. World Meteorological Organization, 79 p.

Nury, A. H., Shah,; S. M. A. and Alam, M. J. B. 2013. Study of rainfall and discharge trends of Kushiyara River in Sylhet. Proceedings of 4th Global Engineering, Science and Technology Conference, Dhaka, 1-9.

Peterson, B. J.; Holmes, R. M.; McClelland, J. W.; Vörösmarty, C. J.; Lammers, R. B.; Shiklomanov, A. I.;Shiklomanov, I. A. and Rahmstorf, S. 2002. Increasing river discharge to the Arctic Ocean. Science, 298: 2171 Ï 2173.

Raghunath, H. M. 2006. Hydrology: principles, analysis and design. New Delhi: New Age International.

Shahid, S. 2010. Rainfall variability and the trends of wet and dry periods in Bangladesh. International Journal of Climatology, 30(15): 2299 ï 2313.

Shiklomanov, A. I.;Yakovleva, T. I.; Lammers, R. B.;Karasev, I. V. and Linder, E. 2006. Cold region river discharge uncertaintyð estimates from large Russian rivers. J. Hydrol., 326: 231256.

Spencer, J. E. and Thomas, W. L. 1987.Introducing cultural geography. New York: John Wiley and Sons.

Tian, J. 1997. Study on the effect of the drying up of the Yellow River on the ecological environment in the sea water near the delta. Marine Environ. Sci., 16(3): 59ï 65.

Trenhaile, A. S. 1997. Coastal Dynamics and Landforms.Oxford University Press, Oxford, UK.

Walling, D. E. and Fang, D. 2003. Recent trends in the suspended sediment loads of the worldôs rivers.Global Planet.Change, 39: 1111125.

Wiegel, R. L. 1996. Nile delta erosion.Science, 272: $338 і ̈ 340$.

Yang, D.; Kane, D.; Hinzman, L.; Zhang, X.; Zhang, T. and Ye, H. 2002.Siberian Lena River hydrologic regime and recent change.J. Geophys. Res., 107(23): 4694.

Yang, Z. and Saito, Y. 2003.Response of the Huanghe (Yellow River) delta evolution to the human activities and precipitation changes. Geophys. Res. Abstracts, 5: 9143.
Yang, Z. S.; Milliman, J. D.; Galler, J.; Liu, J. P. and Sun, X. G. 1998. Yellow River's water and sediment discharge decreasing steadily. EOS Trans. Am. Geophys. Union, 79(48): 589 ï 592.

Ye, B.; Yang, D. and Kane, D. L. 2003. Changes in Lena River stream flow hydrology: Human impacts versus natural variations. Water Resour. Res., 39(7): 1200.

Ye, Q. 1998. Flow interruptions and the environmental impact on the Yellow River delta. Acta Geographica Sinica, 52(5): 385 ï 393. 